\title{
Machtige melodieën : populaire teksten uit de jaren vijftig en zestig als bron voor cultuurgeschiedenis
}

Citation for published version (APA):

Meijer, M. J. H. (1999). Machtige melodieën : populaire teksten uit de jaren vijftig en zestig als bron voor cultuurgeschiedenis. Universiteit Maastricht. https://doi.org/10.26481/spe.19990122mm

Document status and date:

Published: 22/01/1999

DOI:

10.26481/spe.19990122mm

Document Version:

Publisher's PDF, also known as Version of record

\section{Please check the document version of this publication:}

- A submitted manuscript is the version of the article upon submission and before peer-review. There can be important differences between the submitted version and the official published version of record.

People interested in the research are advised to contact the author for the final version of the publication, or visit the DOI to the publisher's website.

- The final author version and the galley proof are versions of the publication after peer review.

- The final published version features the final layout of the paper including the volume, issue and page numbers.

Link to publication

\footnotetext{
General rights rights.

- You may freely distribute the URL identifying the publication in the public portal. please follow below link for the End User Agreement:

www.umlib.nl/taverne-license

Take down policy

If you believe that this document breaches copyright please contact us at:

repository@maastrichtuniversity.nl

providing details and we will investigate your claim.
}

Copyright and moral rights for the publications made accessible in the public portal are retained by the authors and/or other copyright owners and it is a condition of accessing publications that users recognise and abide by the legal requirements associated with these

- Users may download and print one copy of any publication from the public portal for the purpose of private study or research.

- You may not further distribute the material or use it for any profit-making activity or commercial gain

If the publication is distributed under the terms of Article $25 \mathrm{fa}$ of the Dutch Copyright Act, indicated by the "Taverne" license above, 
VAR 124

IVlachtige melodieën

Populaire teksten uit de jaren vijftig en zestig als bron voor cultuurgeschiedenis

Prof. Dr. Maaike Meijer

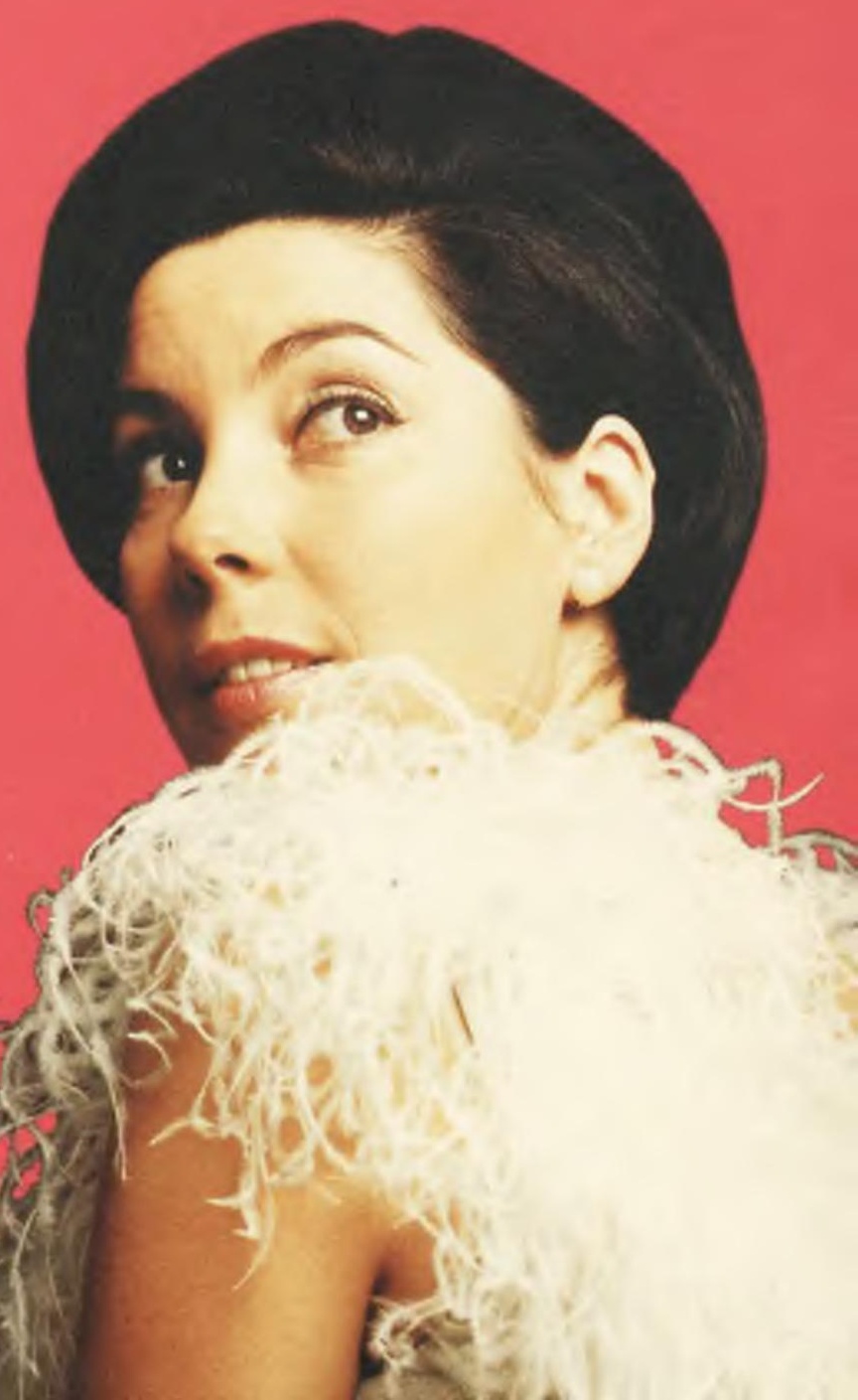

M Universiteit Maastricht 
Universiteitsbibilotheek

Universiteit Maastricht

Postbus 616

6200 MD Maastricht

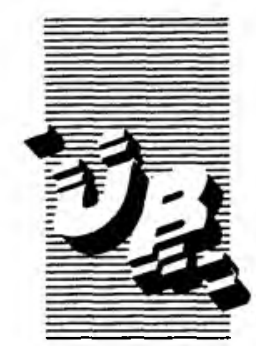

De uitleentermijn verstrijkt op:

\section{O 8 JUNI 1999}

Gelieve deze publicatie tijdig te retourneren of (telefonisch) verlenging van de uitleentermijn aan te vragen. 


\section{Machtige melodieën}

Populaire teksten uit de jaren vijftig en zestig als bron voor cultuurgeschiedenis 



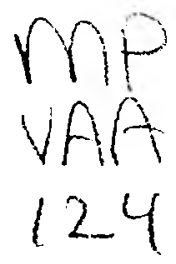

Rede

in verkorte vorm uitgesproken bij de aanvaarding van het ambt van bijzonder hoogleraar vanwege het feministisch maandblad Opzij - leeropdracht 'gender, repesentatie en macht' - en het ambt van gewoon hoogleraar vrouwen- en genderstudies aan de Universiteit van Maastricht op vrijdag 22 januari 1999

door

Prof. Dr. M.J.H. (Maaike) Meijer

Universiteit Maastricht

Centrum voor Gender en Diversiteit 
Centre for Gender and Diversity

Centrum voor Gender en Diversiteit

Universiteit Maastricht

Faculteit der Algemene Wetenschappen

Postbus 616

6200 MD Maastricht

tel: $043-3883389 / 043 \cdot 3882669$

fax: $043-3214428$

e.mail: awgender@cs.unimaas.nl

M.Meijer@genderfdaw.unimaas.nl

M.Bosch@genderfdaw.unimaas.n]

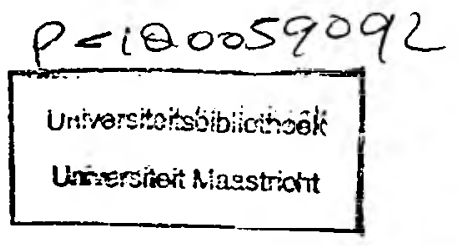


Deze rede werd geschreven in het najaar van 1998 , tijdens een verblijf als research-fellow aan het NIAS (Netherlands Institute for Advanced Studies) te Wassenaar. Ik dank het NIAS voor de geboden faciliteiten en NWO voor de financiële ondersteuning. 


\section{Centrum voor Gender en Diversiteit}

Het Maastrichtse Centrum voor Gender en Diversiteit startte per I september I998, bij het aantreden van Dr. Maaike Meijer als gewoon hoogleraar en van Dr. Mineke Bosch als universitair hoofddocent. Meijer was sinds maart 1998 reeds bijzonder hoogleraar vanwege het feministisch maandblad Opzij. Het Centrum is ondergebracht bij de Faculteit Algemene Wetenschappen.

Genderstudies zijn een verbreding van vrouwenstudies. De onderneming die zich bezighield met de bestudering van vrouwen en het vrouwelijke heeft zich het laatste decennium expliciet uitgebreid naar de bestudering van sekse als formatief sociaal, cultureel, economisch en symbolisch systeem. Dit hield in dat niet meer alleen datgene dat relatief uitgesloten was (marginaal en 'anders' was) zichtbaar en in kaart werd gebracht, maar dat ook het proces van uitsluiting, gerelateerd aan het proces van insluiting (normalisering) werd bestudeerd. Naast de constructie van vrouwen en vrouwelijkheid is het ook van belang om de constructie van mannen en mannelijkheid te bestuderen, niet alleen om de gegenderde sociale orde te begrijpen, maar ook - en meer algemeen - om de werking van macht te analyseren.

Processen van in- en uitsluiting op grond van gender zijn onlosmakelijk verbonden met allerlei andere vormen van verschil en hiërarchisering - op grond van seksualiteit, klasse, ras en etniciteit, nationale en regionale identiteit, religie, leeftijd en validiteit. Op al die gebieden zal het Centrum zich in principe in onderwijs, onderzoek en maatschappelijke dienstverlening bewegen.

Het Centrum bestaat, behalve uit een kernstaf van hoogleraar, hoofddocent, projectmedewerker en aio('s), uit een brede groep medewerkers uit de Faculteiten Cultuurwetenschappen, Economie, Recht, Geneeskunde en Gezondheidswetenschappen. 
Machtige melodieën.

Populaire teksten wit de jaren vijftig en zestig als bron voor cultuurgeschiedenis.

\section{Zeer geachte dames en heren,}

Ik ben blij, en trots en gelukkig dat ik hier vandaag als eerste Opzijhoogleraar het Maastrichtse Centrum voor Gender en Diversiteit officieel mag openen. Het onmisbare feministische maandblad Opzij heeft in 1997 besloten tot het in het leven roepen van een gesalarieerd bijzonder hoogleraarschap, dat de naam van haar oprichtster draagt. Zij heeft tevens besloten dit bijzonder hoogleraarschap voor een periode van vijf jaar te schenken aan de Universiteit van Maastricht (wij Maastrichtenaren vonden dat uiteraard een zeer wijs besluit) en dat werd het begin van het Maastrichtse Centrum voor Gender en Diversiteit. Als eerste bezetter van de Opzijleerstoel kwijt ik mij vanaf I maart i998 een dag per week van mijn leeropdracht 'gender, representatie en macht' - en daaraan zal ik ook deze inaugurele rede wijden.

\section{Culturele representatie}

Het object van mijn onderzoek is de Nederlandse cultuur in de jaren vijftig en zestig. De jaren vijftig staan te boek als de periode van wederopbouw en restauratie na de oorlog, de jaren zestig als de periode die voorbereiding en losbarsten ziet van een groot aantal sociaal-culturele vernieuwingsbewegingen: voorafgegaan door de jeugdcultuur en de seksuele revolutie volgden de provobeweging, de studentenbeweging, de gekkenbeweging, de homobeweging, de kraakbeweging, de antikernenergiebeweging, de vredesbeweging, de milieubeweging, de indobewustwordingsbeweging, de anti-apartheids- en antiracismebeweging en, last but not least, de vrouwenbeweging. Een aantal van die bewegingen 
begon pas echt te bloeien in de jaren zeventig en tachtig, en dat geldt zeker voor de vrouwenbeweging. Vele van de in de Nederlandse cultuur gevestigde verschillen en hierarchieën raken in de jaren zestig ingrijpend op drift. Aangedreven door een grotere welvaart en door de ontwikkeling van nieuwe technologieën die meer vrijheid, meer mobiliteit en meer consumptie mogelijk maakten, raakten de klassieke patriarchale gezagsrelaties onderhevig aan kritiek en erosie: vooral leeftijdsverhoudingen, sekseverhoudingen en normen rond seksualiteit werden betwist. Die veranderingsprocessen en de economische, technologische, sociale, politieke en demografische oorzaken daarvan, zijn inmiddels op ruime schaal onderzocht door historici en sociologen.'

Wat mij nu als cultuurwetenschapper interesseert is de rol die culturele representatie speelt in het uitdokteren en scheppen van andere jongeren en ouderen, van andere mannen en vrouwen, van andere visies op gekte, op seksualiteit, op etniciteit, op gezagsrelaties in het algemeen. Onder culturele representatie versta ik alle teksten en beelden die een cultuur voortbrengt, of dat nu om de zogenaamde 'hoge cultuuruitingen' gaat als poëzie, romans, modern-klassieke muziek en museumkunst, of om 'lage cultuuruitingen' als reclameteksten, het aanbod van televisie en radio, om smartlappen, cabaretteksten, stripverhalen, liederen en de krant. Met het oog op mijn vraagstelling - hoe bemiddelen teksten en beelden in het tot stand komen van nieuwe identiteiten, nieuwe zelfbeelden - zijn al die cultuuruitingen even interessant. De vraag die ik stel aan de teksten en beelden die samen onze cultuur vormen is namelijk niet 'wat is de intrinsieke esthetische waarde van deze cultuuruitingen?' maar: 'welke rol spelen cultuuruitingen in het voortbrengen van andere sekseverhoudingen, andere etnische verhoudingen, van andere normen rond seksualiteit en leeftijd?'2 De produktie van nieuwe visies en nieuwe normen speelt zich niet in het luchtledige van geesten en gedachten af. Gedachten hebben een zeer materiële vorm: de vorm van een culturele tekst. Omdat kinderen van mijn generatie bij Annie Schmidt hebben gelezen 
Ik ben lekker stout

Ik wil niet meer, ik wil niet meer!

Ik wil geen handjes geven!

Ik wil niet zeggen elke keer:

Jawel mevrouw, jawel meneer...

nee, nooit meer in mijn leven!s

daarom hebben wij vervolgens de opstandige gevoelens en gedachten gekregen die de protestgeneratie4 eigen waren, en ook die gevoelens en gedachten hadden een materiële vorm: het waren leuzen die in het geheugen bleven haken, zoals 'Lesbisch zijn is een politieke keuze!', het waren teksten als - ik citeer:

'Vrouwen worden door de heteronorm gedwongen hun belangrijkste relaties te beperken tot leden van de kaste die hen onderdrukt, en weerhouden van relaties met medevrouwen. In dit licht bezien is de heteronorm niet zozeer een seksuele norm, als wel een middel tot instandhouding van de machtsrelatie tussen de seksen.' 5

Aldus luidde een opruiend geschrift van de lesbisch-feministische actiegroep Paarse September. Uiteraard heeft Annie Schmidt niet de hele Paarse September op haar geweten, zo eenvoudig ligt het niet. Niet door het lezen van dat ene gedichtje gingen de kinderen die opgroeiden in de jaren vijftig rebelleren. Er ontstond in de jaren vijftig en vooral zestig een tekstklimaat, een heel conglomeraat van teksten en beelden waarin beginnende sociale veranderingen werden voorbereid, geregistreerd, verwerkt en beantwoord. Ik wil het hebben over dat fascinerende, veelomvattende en alomtegenwoordige proces van culturele representatie, van het almaar circuleren van teksten en beelden en de manier waarop heel veel mensen daardoor gevormd worden. Identiteit, zelfgevoel en groepsgevoel zijn uitermate dynamische disposities. Wij zijn nooit af. Wij worden dagelijks opnieuw herschapen, innerlijk in vorm geduwd en 
veranderd door wat wij zien en lezen. Culturele representatie bevat de nieuwe ideëen, schept ze, radicaliseert ze, weerstaat ze, geeft ze opnieuw vorm. En dat proces van culturele transmissie is het, dames en heren, dat ik vandaag met $U$ op de voet wil gaan volgen.

De demografische, technologische, economische en politieke bronnen van de omwenteling in de jaren zestig laat ik dus graag over aan historici en sociologen. Het gaat mij even kort door de bocht niet om de vermolmde politieke constellatie in de jaren zestig, noch om de verbetering van de stofzuiger en de introductie van de volautomatische wasmachine. ${ }^{6}$ Het gaat mij erom wat de huisvrouw al wassende en stofzuigende beluisterde op de radio7: zij luisterde naar 'Arbeidsvitaminen' (lichte muziek met veel Duitse schlagers, Franse chansons, veel liederen van Nederlandse bodem en naarmate de tijd vorderde steeds meer liedjes in het Engels); zij luisterde naar Mia Smelt, 'Moeders wil is wet'; naar 'De groenteman' - een dagelijks terugkerende dialoog aan de groentekar bij de voordeur, waarin een mannelijke deskundige de huisvrouw voorlichtte omtrent de dagprijzen van de verkrijgbare groenten. Dat waren de culturele 'technologies of gender's die de huisvrouw enerzijds achter haar wasmachine en haar stofzuiger hielden, maar waarin ook regelmatig een ander geluid doorklonk:

Het is nu eindelijk een feit

Ik ben je kwijt, ik ben je kwijt

Je knoeit de as van je sigaar

Nu voortaan verder maar bij haar

zo luidde het begin van het woedende en triomfantelijke scheidingslied van Conny van de Bos: 'Ik ben gelukkig zonder jou'.s Dat was nog eens andere koek dan de spruitjes van de groenteman. Kortom: mij boeien de culturele bronnen van de bewegingen van de jaren zestig. Ik richt me dan vooral op de culturele bronnen van het feminisme. 


\section{Uitschuiftafeldame}

Wanneer wij elkaar in een vroeger leven hadden ontmoet, dames en heren, dan had ik $U$ hier een verhaal verteld over de voorbereiding, vormgeving en betwisting van de feministische revolutie binnen één specifiek cultureel systeem: de Nederlandse literatuur. $U$ weet dat de jaren vijftig en zestig werden gedomineerd door een aantal prozaschrijvers met groot gezag en invloed: W.F. Hermans, Mulisch, Reve, Blaman en Wolkers. Terwijl al deze schrijvers de generatiekloof hebben neergezet en mede geschapen, terwijl Wolkers de literaire profeet was van een op mannen georiënteerde seksuele revolutie, terwijl Blaman en Reve de homobeweging op gang hebben geholpen: van feminisme kunnen ze, met uitzondering misschien van Blaman, nauwelijks verdacht worden. De mannelijke mainstreamschrijvers zijn behoorlijk misogyn. Feministische visies zijn eerder aan te treffen bij auteurs als Hella Haasse en Andreas Burnier, en bij vrouwelijke auteurs die een minder gecanoniseerde status bereikten, als Nel Noordzij, Ankie Peijpers en Aya Zikken.10 Een analyse van de wijze waarop de vrouwenbeweging werd voorbereid, genegeerd, betwist en verwerkt in de Nederlandse literatuur zou buitengewoon interessant zijn - en $u$ kunt hem zeker te zijner tijd van mij verwachten. Maar vandaag geef ik $U$ deze analyse niet.

'Nederlandse cultuur' valt niet samen met 'Nederlandse literatuur' en er is er een zeer groot gebied dat altijd maar buiten het gezichtsveld van historici en cultuurhistorici bljft vallen: het gebied van de populaire cultuur. Met populaire cultuur bedoel ik: lichte muziek, cabaret, radio- en televisieuitzendingen, veelgelezen jeugdliteratuur, musicals. Vergeleken bij de analytische en interpretatieve aandacht die de literatuur ten deel valt zakt de aandacht die aan populaire cultuur wordt gegeven in het niet. Die lijkt geen interpretatie waardig. Er zijn boekenkasten vol interpretaties van W.F. Hermans, maar er is geen cultuuranalytische aandacht voor die andere grote Hermans: Toon. Dat komt niet omdat Toon een Limburger is: het komt omdat hij een cabaretier is. Cabaret is om te lachen, dus kan het geen bron voor de culturgeschiedenis zijn, zo luidt het impliciete oordeel." Dat komt 
Machtige melodieën

toch ook, zult U zeggen, omdat het werk van de ene Hermans (W.F.) zoveel complexer is dan het werk van Toon Hermans. Maar wanneer de vraag is: hoe bemiddelt de culturele tekst in het tot stand komen van andere mannen en vrouwen, van identiteit en subjectiviteit, van groepsgevoel en zelfbesef, van waarden en normen - ja dan worden juist die teksten van Toon buitengewoon interessant. Ik zou de rest van dit uur kunnen wijden aan de wijze waarop Toon Hermans mijns inziens het orthodoxe manbeeld van zijn generatie van voetstuk heeft getrokken om er de hedonistische man, de speelse man, de man als kind voor in de plaats te zitten. Hermans is de man die aanloopt achter het ballonnetje dat danst in de wind, de man die zich voor het oog van heel Nederland in een regressie stort waarin de seksuele nieuwsgierigheid van een zesjarig jongetje, gefascineerd door de maten van het vrouwelijk lichaam, centraal staat. $U$ herinnert zich vast de uitschuiftafeldame, of de Vlaamse mevrouw met haar vorstelijk decolleté, waar Toon het liefst in zou willen verdwijnen. De Toon-tekst verdient des te meer aandacht omdat hij een enorm bereik, een enorme bekendheid en daarom ook een zeer grote invloed had. Datzelfde geldt voor de liederen van Jaap Fischer en Boudewijn de Groot, die de contemporaine mannelijkheid beiden ook ingrijpend herschreven.12 I $\mathrm{k}$ wil $\mathrm{U}$ vandaag overhalen tot de gedachte dat teksten uit de populaire cultuur wel degelijk interessant en complex zijn: complexiteit, zo heeft de leestheorie's ons geleerd, is niet alleen in de tekst aanwezig, maar ook in the eye of the beholder. Het is de complexiteit van de leeswijze die complexiteit in de tekst naar boven kan brengen. Bovendien is het materiaal waarvan tekst en beeld gemaakt zijn uit zijn aard meerlagig. Tenslotte kan elke tekst in een intertekstuele analyse verbonden worden met de repertoires, de vertogen en retorische strategieën waaruit hij put: elke tekst, hoe schijnbaar simpel ook, is onderdeel van een complex cultureel netwerk.

I $\mathrm{k}$ wil twee stellingen verdedigen:

Stelling I: Niet alleen literaire teksten zijn complex, interessant, vormend, normstellend en leverancier van identificatiemodellen: dat is voldoende aangetoond. Ook populaire teksten zijn dat. 
Stelling 2: de feministische revolutie werd - evenals de andere revoluties van de jaren zestig en zeventig - mede in de populaire cultuur voorbereid, vormgegeven en betwist. Daarmee neem ik afstand van het vooroordeel dat populaire cultuur per definitie conservatief en ideologisch rechts is, terwijl literatuur en andere 'hoge' cultuurvormen per definitie progressief en vooruitstrevend zouden zijn. Dat is per tekst verschillend, dat moet per tekst geanalyseerd worden: elke generalisatie is in dezen uit den boze.

\section{Handel in mannen}

Om deze twee stellingen kracht bij te zetten wil ik U nu meevoeren naar het oeuvre van de zangeres Corry Brokken.

Corry Brokken was een zeer bekende persoonlijkheid in Nederland gedurende zo'n vijfentwintig jaar, van 1950 tot 1975 . In 1957 won haar liedje 'Net als toen' het Eurovisie-songfestival in Frankfurt. Ze had grote en

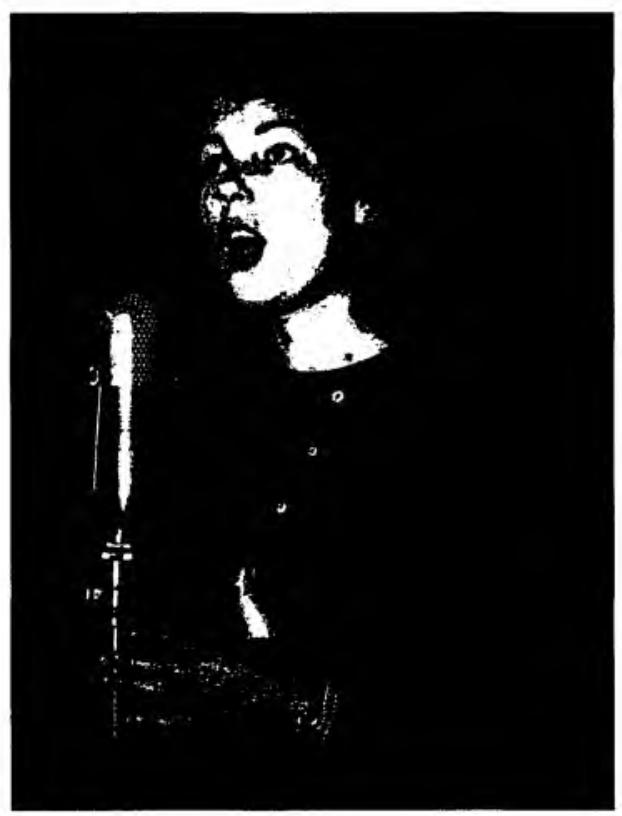
langlopende televisieshows, in Nederland en Duitsland, en maakte onvergetelijke succesnummers zoals 'Milord', 'Mijn Ideaal', 'La Mamma' en 'Heel de wereld'. Ze had - en heeft nog steeds - een schitterende stem en een fenomenale dictie. In 1974 begon ze een ander leven: ze scheidde, ging rechten studeren en werkte van 198 r tot 1997 als advokaat en als rechter in Den Bosch. Op dit moment treedt Corry - nu exadvokaat en ex-rechter - weer op als presentator, dagvoorzitter en incidenteel als zangeres. ${ }^{14}$ In haar eigen leven bestreed ze niet alleen 
de vastgelegde sekserollen, maar ook de leeftijdsstereotypen, die voor oudere vrouwen gemiddeld wat harder aankomen dan voor oudere mannen. De reden dat ik Corry Brokken hier ten tonele voer is echter niet dit persoonlijke levensverhaal, hoezeer dat een feminist ook als muziek in de oren moge klinken. Het gaat mij om de inhoud van Brokkens liederen. Daarin beluister ik zowel conservatieve geluiden, spiegels van de toenmalige sekse-orthodoxie, maar ik zie er ook smeulende brandhaarden van onvrede in. Daarop baseer ik de gedachte dat de populaire cultuur niet braaf wacht tot 1967 , het moment dat Joke Kool Smit haar befaamde Gids-manifest 'Het onbehagen bij de vrouw' publiceert. Al jaren vóór dit officiële startschot van de vrouwenbeweging wordt in de lichte muziek geprotesteerd tegen de orthodoxe seksevoorschriften, en dit protest bereikt, in tegenstelling tot dat van Joke Smit, in één klap miljoenen vrouwen. Laten wij luisteren naar het lied 'Mijn Ideaal'. Daar is een vrouwelijk 'lyrisch ik' aan het woord die haar echtgenoot aanspreekt in een lange monoloog. Zij breekt deze man - en het huwelijk - werkelijk tot op de grond toe af. Aan het slot zit een draai die dit lied weer hoogst conformistisch maakt: de vrouw blijft zitten in dit barrel van een huwelijk, verbazingwekkend na alle desillusie die zij heeft geëtaleerd. Wat is dat voor een compromis? Hoe geloofwaardig is het? Als we het lied hebben doorgelezen zal ik het aandachtig met $U$ interpreteren, alsof het een gedicht is:

\section{Mijn ideaal}

In het begin heb ik als je vrouw Mijn ideaal gezien in jou Je was zo stoer en zo sportief Je had mij zo onstuimig lief Je kuste mij zo resoluut Ja, af en toe een beetje bruut Je had zo'n echt piratenbloed Zo'n ongetemde overmoed. 
Nu ben je je sportiviteit

En al je wilde haren kwijt

Mijn Ridder van het eerste uur

Jouw slank figuur werd op den duur

Het welgedane proza van

De goedgeslaagde zakenman

En jij hebt niets waarin een vrouw

Nog poëzie ontdekken zou

En toch was jij die eerste maal

Mijn ideaal, mijn ideaal

Eens was je geestig en ad rem

Nu praat je enkel van tantième

Thuis maak je ruzie om een cent

Maar in je Club de vlotte vent

Daar komen vrienden naar je zin

Met net zo'n dubbele onderkin

En de allures heb je nog

Maar voor de spiegel ben je toch

Ondanks je branie en bravour:

Een jeune premier op z'n retour!

Je komt naar huis toe elke dag

Een moede man vol zelfbeklag

En geeft een lauwe kus, uit sleur

Jij, eens mijn vurige charmeur!

Mijn Cyrano de Bergerac

Wenst dat ik flensjes voor hem bak!

Wat werd je burgerlijk banaal

Mijn ideaal, mijn ideaal

Je bent zo ijdel als een pauw

En slooft je uit voor elke vrouw

Je hebt een permanent complex

Of jij nog meetelt met je sex

Je cultiveert je dunne haar 
En parfumeert het veel te zwaar

Dan speel je tennis en je flirt

Totdat je kou vat in je shirt

Dan breng je bloemen voor me mee

En ik geef jou kamillethee

En toch, als ik je dan zo zie

Zo stil en vol melancholie

Dan voel ik soms een ogenblik

Dat jij alleen bent net als ik

Dan is die hulpeloze man

Die toch mijn zorg niet missen kan

Mij nog het liefst van allemaal

Mijn ideaal, mijn ideaals

Ik weet dat er veel feministen in de zaal zitten, mannen zowel als vrouwen, die zich bij het horen van de laatste regels waarschijnlijk brakend willen afwenden. Wacht, loop niet weg. Interessant aan dit lied is juist de ambivalentie ervan. Laten we deze tekst eens serieus nemen. ${ }^{6}$ Het is een lyrische tekst, met een klassieke lyrische taalsituatie: een 'ik' houd een monoloog tot een afwezige iets of iemand anders, en wij als luisteraars luisteren die monoloog, die eigenlijk niet voor onze oren is bestemd, af.r7 Wat zegt die 'ik' tegen haar echtgenoot? Eens was jij 'mijn ideaal' maar die tijd is allang voorbij. De vroeger ideale man wordt in de eerste strofe in zeer conventionele termen geschetst:

Je was zo stoer en zo sportief

Je had mij zo onstuimig lief

Je kuste mij zo resoluut

$J a$, af en toe een beetje bruut

Je had zo'n echt piratenbloed

- een constructie van mannelijkheid met net even die hint naar bruutheid als onderdeel van de mannelijke charme, waar ik als feminist weinig 
waardering voor kan opbrengen. Hier sluit 'Mijn ideaal' naadloos aan bij een conservatieve ideologie van mannelijkheid. Maar vervolgens wordt deze man, en daarmee het mannelijkheidsideaal, werkelijk tot op de grond toe afgebroken. Zijn lelijk geworden figuur, zijn dubbele onderkin passeren de revue, zijn saaiheid, zijn uitgeblustheid, de sleur waarmee hij zoent, zijn narcistische seksobsessie, zijn krenkende geflirt, het gaat van kwaad tot erger. Het lied is vanaf de tweede strofe opgebouwd als een enumeratio, een opsomming die toeneemt in kracht. Een enumeratio leidt vaak tot een climax, weten we uit de retorica. ${ }^{8}$ De climax lijkt alleen nog maar te kunnen zijn dat deze 'ik' haar man verlaat. Maar dat gebeurt niet: de laatste strofe laat een enorme draai terug zien.

En toch, als ik je dan zo zie Zo stil en vol melancholie Dan voel ik soms een ogenblik Dat jij alleen bent net als ik

Vooral die regel 'dat jij alleen bent net als ik' is een bijzonder intrigerende. Hij valt uit de toon, hij vormt een onverwacht zijspoor, een deconstructief moment in deze tekst. Wat betekent die regel? Dat die ouder wordende man niet langer het clichémacho-type is, waardoor het opgeklopte man-vrouwverschil is weggevallen? Dat de vrouw zelf ook 'stil en vol melancholie' is, net zoals alleen hij dat kan zijn? Of betekent het dat de 'ik' heel even inziet dat niet alleen haar man op zijn retour is, maar ook zijzelf? Want zelf zal zij in dit huwelijk ongetwijfeld ook zijn gaan slijten - maar dat is tot nu toe allemaal weggestopt achter de woede over het feit dat die echtgenoot zo'n sof blijkt te zijn. Misschien wordt in die ene zin heel even door deze vrouw erkend dat zij zelf even leeg, even pompeus, evenzeer op haar retour is als hij. Maar dit moment van zelfinzicht - en verlies van illusies omtrent haarzelf - wordt onmiddellijk weggespoeld door de visie op de man als hulpeloos: 
Dan is die hulpeloze man

Die toch mijn zorg niet missen kan

Mij nog het liefst van allemaal

Mijn ideaal, mijn ideaal

Ergo: ik kan niet kwaad op je zijn want je bent zo zielig. De hulpeloosheid van de man legitimeert in deze regels de smadelijke aanpassing van de vrouw zelf: ik ga leven om voor jou te zorgen. Ik ben er voor jou, jij hebt mij nodig. Dat is wel een heel schrijnend einde. Op die manier hebben getrouwde vrouwen zich decennia lang zowel gewroken op hun echtgenoten (je bent hulpeloos zonder mij) als zich verzoend met hun afgeleid bestaan. Ofschoon dit lied dus buitengewoon reactionair eindigt representeert het toch een vertoog over vrouwelijke desillusie en woede, en bewijst het ook dat een dergelijk vertoog anno i 960 al denkbaar was. Er bestond een discours dat het huwelijk vanuit vrouwelijk perspectief schetste als een brok ellende. Mocht dat alleen maar gezegd worden als de vrouwelijke 'ik' na die tirade nadrukkelijk bakzeil haalde? Nee. Het oeuvre van Annie Schmidt telt een aantal liederen die de man ook werkelijk de deur uitdoen, bijvoorbeeld 'Het is over' ( 1965$)$, destijds onnavolgbaar gezongen door Conny Stuart:

't ls over.

Hij zegt me niets meer.

[...] Ze mag hem hebben

Dit lied bevat een tirade van een vrouw tegen haar echtgenoot, die sterk herinnert aan de soortgelijke tirade uit 'Mijn Ideaal':

Die man die thuis kwam 's avonds laat, zo moedeloos en prikkelbaar, dat alles is mijn zorg niet meer.

Dat is nou allemaal voor haar.

Ze mag hem hebben.

[...]

Z'n leugens en zijn draaierij, 
$z^{\prime} n$ minderwaardigheidscomplex,

$z$ 'n sympathie voor Feijenoord,

$z$ 'n bril, z'n sokken en z'n sex.

Ze mag hem hebben.

Deze man wordt dus, $U$ hoort het, overgedragen aan een andere vrouw, de rivale, die expliciet wordt aangesproken:

Het valt niet mee hoor, mooie poes!

Je hebt er tact voor nodig, meid!

De tekst eindigt met de vergelijking van deze man met het speelgoed uit haar jeugd, dat aan een vriendinnetje wordt gegeven:

Hier is het.

Je mag het hebben.

[...] En veel geluk,

maar een ding vraag ik je. Maak het niet stuk.19

Ofschoon er op het nippertje nog enige sympathie voor deze man doorkomt, is 'Het is over' al veel minder ambivalent dan in 'Mijn Ideaal', waar de vrouw in het failliete huwelijk blijft. Ook Schmidts onsterfelijke tekst 'Zeur niet' $(1965)$ is een werkelijk woedende tirade tegen het het huwelijk en het huisvrouwelijk bestaan:

als de echtelijke liefde je tot hier zit,

[...] Trap om je heen,

wees nooit een dame

en gooi het theeservies

dwars door de ramenº

De boodschap van de ' $i k$ ' aan haar mede-vrouwen is: breek de tent af als je wilt, maar zeur niet. Of: wij vrouwen weten allemaal hoe rot het is, maar 
erover praten lost niets op. Omdat het lied uiteindelijk natuurlijk wél praat, en alle vrouwelijke onvrede met bakken over de lezer/luisteraar uitstort representeert dit lied in optima forma het vertoog van 'het onbehagen bij de vrouw'. We kijken hier ongetwijfeld naar een krachtige pretekst 2 van Joke Kool-Smits feministisch manifest. Praten was nu precies dat wat de feministen na I970 gingen doen.22 Terwijl Schmidt het onbehagen bij de vrouw al uitgebreid stem gaf kon zij de stap naar het praten erover nog niet volmondig zetten. Ze noemde dat 'zeuren'. Maar evengoed schalden 'Ik ben gelukkig zonder jou', 'Mijn ideaal', 'Zeur niet' en 'Het is over' via 'Arbeidsvitaminen' al die huiskamers binnen, waar de Nederlandse huisvrouwen met hun stofzuigers in de weer waren. Het gaf hen ongetwijfeld te denken. Even interessante stof tot denken leverden de liedjes van Corry Brokken waarin de 'ik' werkelijk opstapt uit een teleurstellende relatie, zoals 'Ik moet weg':

Ik moet weg. Ik moet ver weg.

I $k$ moet weg van jou, want ik hou van jou.

Jij wil me niet. Jij ziet me niet.

Jij flirt maar, jij lacht maar, jij doet maar

En jij alleen jij, jij was geen uur uit mijn gedachten

Ik ga. Ik bliff niet meer bij jou.

Ik moet weg. Ik moet ver weg.

$J_{i j}$ bent harteloos. $k$ ben radeloos.

Een ander land, een heel nieuw land.

Daar kan ik voor altijd vergeten

Waarom ik gaf aan jou: liefde.

Ik zoek een man, die man.

Een man die om mij en mijn liefde vraagt.

Een man die mij altijd op handen draagt.

Een man die ontdekt wat ik voor hem voel.

Een man die begrijpen wil wat ik bedoel. 
Ik moet weg. Ik moet ver weg.

Naar een ander land, een heel nieuw land

Waar ik kan vergeten en waar ik zal weten

Dat ik werkelijk leven kan zonder jou.

Jij was hard voor mij. Ik ben hard voor jou.

En ik ga van je weg. Ik ga weg! ${ }^{23}$

Zo, dat is andere koek dan 'Mijn Ideaal'. Brokken zingt in hetzelfde genre nog een tamelijk revolutionair lied: 'Hou je van ' $m$ ', ook gecovered door Nina Simone als 'You can have him'. Daarin spreekt een vrouw een medeminnares aan met de boodschap dat zij hem, haar man, mag hebben omdat ze finaal op hem is uitgekeken. En weer wordt de hele geschiedenis van het teleurstellende huwelijk afgespeeld en hoe dat zich jarenlang voortsleepte:

Dus als jij met hem wil trouwen

Ga je gang, je mag hem houwen

Want hij is geen man voor mij ${ }^{24}$

'Hou je van ' $m$ ' heeft een treffende verwantschap met Schmidts 'Het is over', omdat in beide teksten sprake is van een onversneden handel in mannen. In beide teksten biedt de ene vrouw haar man aan aan de andere vrouw, haar rivale. Maar deze rivale wordt toegesproken, niet als vijandin, maar bijna als kameraad, als lotgenoot, als jonger 'ik' die nog illusies koestert omtrent de romance met een man. Dit is een omkering van de klassieke vrouwenruil, volgens Lévi-Strauss, Gayle Rubin en veel feministische theoretica's de grondslag van de patriarchale samenleving: mannen vormen onderling sociale relaties door het uitwisselen van vrouwen. 25 In deze teksten ontsnapt het lyrisch ik echter aan de positie van ruilobject: zij ruilt zelf, en maakt daarmee haar man tot object en de andere vrouw tot mede-subject. Dynamiet, lijkt mij. 
Machtige melodieën

\section{Vreemdgaan}

Wat ik wil laten zien is dat Corry Brokkens 'Mijn Ideaal' onderdeel is van een heel conglomeraat aan teksten waarin vanuit vrouwelijk perspectief een failliet huwelijk wordt beschreven: teksten die elkaar echoeën, hernemen en herhalen, en waarvan 'Mijn Ideaal' eigenlijk veruit het conservatiefst is. In mijn boek In tekst gevat heb ik een analyse gemaakt van Willem Elsschots beroemde gedicht 'Het huwelijk', waarin een man met spijt en woede naar zijn ouder wordende vrouw kijkt.26

Toen hij bespeurde hoe de nevel van den tijd in d'ogen van zijn vrouw de vonken uit kwam doven, haar wangen had venweerd, haar voorhoofd had doorkloven toen wendde hij zich af en vrat zich op van spijt.

Ook deze echtgenoot blijft bij zijn vrouw, na een opmerkelijk uit de toon vallende regel waaruit twijfel en verborgen saamhorigheid blijkt:

[...] want tussen droom en daad staan wetten in den weg en praktische bezwaren, en ook weemoedigheid, die niemand kan verklaren,

Die 'weemoedigheid die niemand kan verklaren' is het deconstructieve moment in 'Het huwelijk', vergelijkbaar met 'dat jij alleen bent net als ik', de ene regel die vloekt en wringt in 'Mijn Ideaal'. Destijds heb ik bij mijn analyse van Elsschot lang gezocht naar gedichten die nu eens vanuit vrouwelijk perspectief een uitgewoond huwelijk zouden beschrijven. Die gedichten vond ik ook, bij tamelijk onbekende dichteressen. Maar U ziet dat dit soort teksten ook verrassend rijkelijk voorkomt in de populaire cultuur.27 Interessant is daarbij dat het lied als genre zeer veel ruimte geeft aan zangeressen, en daarmee een boeiend stuk historische vrouwencultuur representeert, dat door feministische cultuuronderzoekers nodig bestudeerd moet worden. Het luisterlied was en is voor zeker de helft een vrouwelijk 
domein: denk aan Fien de la Mar, Jasperina de Jong, Connie Stuart, Jenny Arean, Ria Valk, Teddy Scholten, Liesbeth List, Liselore Gerritsen, Martine Bijl, Conny van den Bos, Conny Stuart, Anneke Grönloh, Trea Dobbs en een treetje lager in het levenslied Tante Leen, de Zangeres Zonder Naam, Willeke Alberti, Zwarte Riek, Corry en haar rekels. Internationaal is dat overigens ook zo: Edith Piaf, Juliette Gréco, Barbara, Rika Zarai, Anne Sylvestre, Frida Boccara in het Franse chanson, Zarah Leander, Marlene Dietrich, Hildegard Knef, Conny Froboess, Nana Mouskouri, enzovoorts. Ook al worden hun teksten vaak door mannen geschreven, de zangeressen interpreteren ze. De lyrische vorm in het lied impliceert dat er een vrouwelijke 'ik' aan het woord is die haar ervaringswereld en visie formuleert, haar innerlijk neerzet. Het lied biedt dus interessante representaties van vrouwelijke subjectiviteit. En ook al verstrekken de mannelijke tekstschrijvers ${ }^{28}$ soms teksten die eerder getuigen van mannelijke fantasieën over vrouwen dan van vrouwelijke subjectiviteit, toch zingt de zangeres zich als mede-auteur van het lied menigmaal boven die projecties uit.29 Ze hebben daarbij een verspreiding, een populariteit en een invloed die veel groter was dan die de literaire schrijfsters in de jaren vijftig en zestig konden bereiken. De schrijfsters moesten in die decennia altijd opboksen tegen een niet zelden seksistische literaire kritiek en een mannelijk gedomineerd literair establishment. In de liederen komen vrouwen aan het woord from all walks of life': comédiennes, huisvrouwen, tomboy-achtige cowgirls als Ria Valk, die weliswaar zong 'ik wil een cowboy als man', maar als ik naar haar keek, jong lesbootje verdoold in de jaren zestig met Andreas Burnier als de Bijbel onder mijn arm geklemd, dan dacht ik: 'jij wilt helemaal geen man en je bent maar wat blij dat jouw Rockin' Billy naar Amerika is vertrokken'. Jonge verliefde meisjes zijn er bij massa's in het lied, maar ook prostituees, zoals in 'Milord' gezongen door Edith Piaf en Corry Brokken en zelfs moordenaressen: Ali Cyaankali.3o Verlaten vrouwen zijn er vele en dat thema wil ik even nader met $U$ bekijken. Het is fascinerend hoe wijdverspreid in de jaren vijftig en zestig het vertoog in cabaret en lichte muziek over mannelijk vreemdgaan is. In alle teksten die ik tot nu toe besprak wordt mannelijk vreemdgaan genoemd als onlosmakelijk deel van het huwelijk. U hoorde het in 'Mijn Ideaal': 
Dan speel je tennis en je flirt

totdat je kou vat in je shirt

Dan breng je bloemen voor me mee

ja die kennen we, die bloemen, en dan komt zij met de kamillethee.

Schmidt is in 'Zeur niet' aanzienlijk cynischer:

als je man weer met een juffrouw op de pier zit

als de echtelijke liefde je tot hier zit

[...]

sla dan woedend met de deuren,

ga je cocktail-dress verscheuren,

maar niet zeuren. 31

In Schmidts 'Het is over' gaat het zo:

Het wachten in het grote bed

dat was het ergste, o, mijn God,

het aldaar wachten op zijn tred

en op de sleutel in het slot.

Ze mag hem hebben.//

Zijn leugens en z'n draaierij

Verderop, na een herinnering aan gezamenlijke reisjes naar Parijs:

'Maar later ging hij zonder mij,

kwam thuis met lipstick op zijn das.

Ze mag hem hebben.' 32

Ook in Brokkens lied 'Ik ga weg' zit een verwijzing naar ontrouw: 'Jij flirt maar, jij lacht maar, jij doet maar'. En in Brokkens 'Hou je van ' $m$ ' gaat het om: 
Brieven vinden in zijn ouwe pak

uren dwalen door het lege huis

lieve hemel, komt hij nóg niet thuis.

Het thema van de mannelijke ontrouw is alomtegenwoordig.33 Denk aan Teddy Scholtens liedje 'Een beetje':

Een beetje, ja dat weet je soms vergeet je wel een beetje gauw je eedje, van trouw. [.. en als jij vraagt 'Ben je trouw?' zeg ik nooit tegen jou: een beetje

Niet alleen de zangeressen zijn ermee bezig maar ook de zangers. $U$ herinnert zich vast Toon Hermans' conférence 'Vader gaat op stap' nog, waar vader danst met een vreemde dame die ergens een vlekje heeft ('net of 't vlekkie groter wordt'). Deze vader gaat al gauw veilig terug naar moeder de vrouw, die ongetwijfeld met de kamillethee klaarstaat. Er bestaat daarentegen tot in de jaren zeventig praktisch geen vertoog over vrouwelijk vreemdgaan. De overdadige vrouwelijke promiscuiteit in De schaamte voorbij van Anja Meulenbelt is wat dat betreft een gigantische inhaalmanoeuvre. Vóór die tijd is vrouwelijk vreemdgaan bijna unspeakable, behalve bij Wim Sonneveld en hij is zowat de enige. Ik doel hier op de Tearoom Tango: 'Je hebt me belazerd/ je hebt me bedonderd' (waarbij het de vraag is hoe reëel het venijn in dat lied tot een vrouw gericht was, gezien Sonnevelts homoseksualiteit, die vele van zijn liederen tot 'Rollengedichte' maakt: het lied getuigt van een fantastisch ruim geëtaleerde nichterigheid, die vele toeschouwers in die tijd overigens totaal niet in de gaten hadden)34. Het vertoog over mannelijk vreemdgaan is niet typisch Nederlands, maar internationaal. Denkt U aan Connie Francis: 'Lipstick on your collar/ Told a tale on you/ lipstick on your collar/ said you were untrue'. Dit vertoog over het mannelijk vreemdgaan impliceert een erkenning en een constructie van een van mannen min of meer geaccepteerde promiscuiteit. Dat vertoog knakt in de jaren zeventig en tachtig definitief, zowel in de nieuwe vrouwenliteratuur, als ook in films en andere populaire teksten. Het knakt op twee manieren: ten eerste slikt de bedrogen echtgenote haar verdriet niet meer weg, maar neemt zij uit volle borst wraak. Denk aan de film Mamma is 
Boos! waar de gekrenkte echtgenote een (letterlijke) orkaan van woede wordt, of aan Fay Weldons roman Life and Loves of a She-Devil. Ten tweede gaan vrouwen zich nu in gelijke mate aan vreemdgaan tebuiten. Er is een ware stroom van hedendaagse smartlappen waar verwoeste mannen zuchten onder de slagen van vrouwelijke ontrouw en afwijzing: André Hazes' 'Ik slaap vanavond op de bank schat' is hier het prototype. Het is nu de trouw van de vrouw, waarom gevochten moet worden. Het is dat kamillethee uit is, anders kregen de heterovrouwen onder ons heel wat kamillethee geserveerd van hun bevreesde echtgenoten.

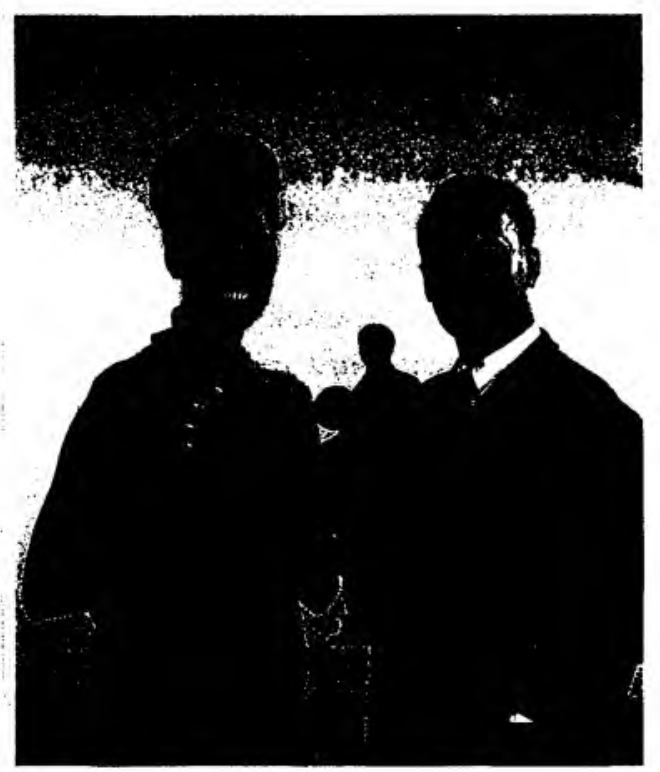

De obsessie met de echtelijke trouw van mannen in de populaire cultuur van de jaren vijftig en zestig had alles te maken met het feit dat het in stand houden van het huwelijk voor vrouwen toen nog letterlijk van levensbelang was: het percentage gehuwde vrouwen met een baan was in de jaren vijftig te verwaarlozen. Bijstand en kinderopvang bestonden niet en scheiden was een schande. Buiten haar huwelijk kon een gehuwde vrouw geen kant op.35 Het was dus laveren tussen het oogluikend toestaan van slippertjes, het verbijten van het verdriet en de vernedering en het toch klaar blijven staan voor je man. Het lied getuigt hier van een zeer wankel maatschappelijk evenwicht dat op het punt stond te barsten in het feminisme dat volgde op de seksuele revolutie.

Welnu, ik hoop dat $\mathrm{U}$ zo langzamerhand warm begint te lopen voor de stellingen die ik aan het verdedigen ben: ten eerste dat ook populaire teksten studie en interpretatie waard zijn, dat ze interessant zijn, zowel om zichzelfs wille als als bron voor de cultuurgeschiedenis. Ten tweede hoop ik dat $U$ ervan overtuigd begint te raken dat de feministische revolutie - 
evenals de andere revoluties van de jaren zestig en zeventig - mede in de populaire cultuur van de jaren vijftig en zestig werd voorbereid en vormgegeven. Dat populaire cultuur per definitie conservatief, bevestigend en ideologisch rechts zou zijn lijkt mij, zoals gezegd, een vooroordeel. Dat kan alleen per tekst beslist worden. Generaliseringen zijn uit den boze. En om dat te bewijzen zou ik tot slot de generalisering te lijf willen gaan dat de in de jaren zestig uit de rock \& roll ontluikende popmuziek zo vernieuwend, hemelbestormend, progressief en revolutionair zou zijn. De popmuziek kwam uit Engeland ons land binnen in de gedaante van The Beatles en The Stones in 1964, en het blad Muziek Express begeleidde dit proces. Deze nieuwe muziek voor teenagers was een concurrent voor het Nederlandse lied van de zangeressen Brokken, Grönloh, Stuart cum suis - maar beide genres bleven ook parallel aan elkaar bestaan en bedienden een verschillend, maar deels ook overlappend publiek. Omdat er tot 1964 nog maar één televisienet was bereikten de zangeressen, de series, kinderprogramma's en Eurovisiefestivals miljoenen in één klap - een uniek moment in de mediageschiedenis, dat een groot contrast vormt met de huidige diversificatie van media en mediapubliek. Maar waarover zingen de Beatles in hun begintijd nu eigenlijk? Hun werk was muzikaal zeker nieuw, $3^{6}$ maar tekstueel was het heel conventionele, mierzoete romantiek van jongens en meisjes die net aan de liefde begonnen: 'I want to hold your hand'; 'She loves you yeah yeah yeah'. In een aantal liedjes spelen jongens elkaars go-between ('She loves you') of verdelen zij de meisjes onder elkaar: 'If you don't treat her right my friend you'll be the lonely one. You're gonna lose that girl'. Wat the girl er zelf van vond horen we niet van de Beatles, maar van meisjesgroepen als The Surpremes en de Shangri Las, die in de jeugdcultuur echter veel dunner gezaaid waren dan de vrouwelijke zangers in de continentale liedcultuur. En herinnert U zich 'A hard day's night' nog?

It's been a hard day's night, And l've been working like a dog, It's been a hard day's night, I should be sleeping like a log, 
But when l get home to you, I find the thing that you do, Will make me feel alright.

$[\ldots]$

When I'm home ev'rything seems to be right, When I'm home feeling you holding me tight, tight yeh.37

De kamillethee druipt ervan af. De vroege Beatlesongs zijn zeker niet zo aartsconservatief als 'A Woman's Place' (is in the Home) of 'Matrimony' van Gilbert O'Sullivan:

You and me are all that matters, disregard the rest Trust your soon-to-be your man, he knows what is best Very shortly now there is gonna be an answer from you And one from me: it's matrimony.

maar het blijft bij The Beatles draaien om de ervaringswereld van jonge mannen, die er geen belang bij hebben de heersende sekseverhoudingen te ondervragen. Vanuit genderperspectief bezien betekent de stormachtige introductie van de popmuziek dat jonge mannen het geheel voor het zeggen krijgen in de populaire cultuur. De muziek waarin relatief veel ruimte was voor volwassen vrouwen zakt naar het tweede plan. Het interessante is dat de liederen die ik vandaag met $U$ heb behandeld inhoudelijk veel meer gemeen hebben met het snoeiharde cynische Stoneslied 'I can get no satisfaction', dan met de zoete vroege Beatle-liedjes. 


\section{Dankwoord}

Graag dank ik U dames en heren voor uw belangstelling bij de eerste oratie vanuit ons Maastrichtse Centrum voor Gender en Diversiteit. Er zullen er nog verschillende volgen, want de volgende Opzij-hoogleraar zal over een aantal maanden haar plaats naast mij innemen. Ik functioneer dan niet meer als Opzij-hoogleraar, maar inmiddels wel als hoogleraar-directeur van dit Centrum. Dat centrum zal vele interdisciplinaire onderwijs- en onderzoeksaktiviteiten gaan ontplooien, zowel binnen de deelnemende faculteiten als binnen het Centrum zelf. Mijn eigen onderzoek en dat van de groep die ik om mij heen hoop te verzamelen zal zich richten op het in Nederland nog vrij nieuwe vakgebied der 'cultural studies': de studie van Nederlandse tekst- en beeldcultuur uit high en low culture na de oorlog, vanuit de vraag hoe deze teksten en beelden maatschappelijk functioneerden. Mijn grote voorbeeld is daarbij het befaamde Engelse Centre for Contemporary and Cultural Studies oftwel de 'Birmingham School', gegrondvest door Raymond Williams en uitgebouwd door Stuart Hall, dat ook vele feministische en postkoloniale geleerden heeft geinspireerd tot studies van contemporaine cultuur, waarbij het onderscheid tussen 'high' en 'low' culture wordt losgelaten. U weet dat het een tijdje mode was dat Nederlandse universiteiten zich vergeleken met grote buitenlandse voorbeelden. Leiden noemde zich het Yale aan de Noordzee, Utrecht wou graag het Berkely van de Veluwe zijn. Welnu, dan is Maastricht het Birmingham aan de Maas, als het aan mij ligt. Ik dank het College van Bestuur, dat de wijsheid heeft gehad dit centrum in te richten, en Hans Philipsen, onze speciale adviseur. Ik dank Kasper Boon en Annet Habets, respectievelijk dekaan en directeur van de Faculteit Algemene Wetenschappen, die mij zo bijzonder hartelijk in hun Faculteit hebben ontvangen en met raad en daad bijstaan. Ik dank de collega's van het Interfacultair Vrouwenstudies Overleg, verspreid over de Faculteiten Cultuurwetenschappen, Economie, Recht, Geneeskunde en Gezondheidswetenschappen, die met hun beleidsplannen omtrent de uitbouw van studies van gender en diversiteit mede vorm geven aan ons 
centrum. Ik voel mij rijk en gelukkig met zo'n prachtig stel collega's. Ik dank eenieder die hier in Maastricht de studies van gender en diversiteit een warm hart toedraagt: ik geloof hier precies het vernieuwende en interdisciplinaire klimaat te hebben gevonden waarin ons Centrum voor gender en diversiteit kan bloeien. Tenslotte dank ik mijn naaste collega's die nu al in de kern van mijn centrum werken: Dr. Mineke Bosch hoofddocent, Drs. Steffie Jansen onze eerste aio, Dr. Ruth de Kanter projectmedewerker, die mij ook zo hartelijk logies verschaft in Maastricht en natuurlijk de secretariële en organisatorische ondersteuners Yvette van Kampen en Marita Doijen. En dan nu: Feest! 


\section{Noten:}

- Zie bijvoorbeeld Hans Righart, De eindeloze jaren zestig. Geschiedenis van een generatieconflict Amsterdam: Arbeiderspers 1995; J.W. Duyvendak e.a.(red) Tussen verbeelding en macht. 25 jaar nieuwe sociale bewegingen in Nederland. Amsterdam: Sua 1992

2 Zulke vragen worden gesteld binnen het relatief jonge interdisciplinaire vakgebied 'cultural studies'. Zie voor een schets van dit vakgebied Maaike Meijer, 'Van literaire naar culturele studies' in: In tekst gevat. Inleiding tot een kritiek van representatie. Amsterdam: Amsterdam University Press 1996: 85-100

3 Annie Schmidt, Ziezo. De 347 kindenversjes. Amsterdam: Querido 1987: 166

4 Becker $(1983)$ onderscheidt de 'protestgeneratie', geboren tussen 1940 en I955, die zou zijn opgevolgd door een 'verloren generatie', geboren tussen 1955 en 1970. Duyvendak c.s. (1992) en Kriesi en Castenmiller (I987) betwisten die indeling in generaties door te laten zien dat de zogeheten verloren generatie 'een doorslaggevende bijdrage aan het massale protest in de jaren tachtig heeft geleverd' (Duyvendak e.a. 1992:38)

5 Stephanie de Voogd 'Feminisme en homoseksualiteit' in: Paarse September no. 3, maart 1973. Zie ook Maaike Meijer, 'Paarse September. Een documentaire' in: Gert Hekma e.a. (red) Goed verkeerd Amsterdam: Meulenhoff $1989: 183-197$

6 Zie over de betekenis van de ontwikkeling van huishoudelijke apparaten Ruth Oldenziel en Carolien Bouw (red) Schoon genoeg. Huisvrouwen en huishoudtechnologie in Nederland 1898-1998 Nijmegen: Sun 1998

7 Aan het einde van de jaren vijftig was de radio uitgegroeid tot hét massamedium bij uitstek: in 1959 bezat $99 \%$ van de Nederlandse huishoudens een toestel. Vrouwen tussen de 29 en 40 - het meest aan huis gebonden vanwege het sterke huisvrouwenideaal - luisterden het meest. Jonge en middelbare mannen, veel van huis, luisterden het minst. De programmering was ook sterk naar sekse gediffentieerd: 
vrouwenprogramma's in de ochtend en vroege middag, nieuwsuitzendingen bij thuiskomst van de mannelijke kostwinner, 's avonds de programma's voor het hele gezin. Zie Huub Wijfjes (red) Omroep in Nederland 1994: 59, 64, 307.

8 De term 'technologies of gender' ontleen ik aan Teresa de Lauretis, Technologies of Gender Bloomington etc: Indiana University Press, I987

$9 \quad$ Afgedrukt in: Vic van de Reijt (red) Toen wij van Rotterdam vertrokken. Nederlandse liederen uit de zoe eeuw. 8e druk Amsterdam: Bert Bakker, I992: 26I-62

Zie voor een studie van Haasse, Noordzij, Zikken en Burnier het proefschrift van Petra Veeger, Manoeuvres. Proza uit de jaren vijftig en zestig, Delft: Eburon 1996. Veeger laat zien hoe bewust én literairvernieuwend sekseongelijkheid werd verbeeld in een viertal representatieve teksten van deze auteurs. Voor de feministische lading in het werk van Peijpers in de jaren vijftig en zestig zie mijn inleiding tot Ankie Peijpers, Gedichten 1951-1975 Amsterdam: An Dekker I991: i-xiii. Voor prefeminisme in het werk van Nederlandse dichteressen in de jaren vijftig zie Maaike Meijer, 'De grote melancholie' in: De lust tot lezen I988: $287-346$

"Het gedane cabaretonderzoek niet te na gesproken. Wim Ibo schreef met En nu de moraal... (198I) de eerste geschiedenis van het Nederlandse cabaret $1895-1970$. Van den Hanenberg en Verhallen, Het is weer tijd om te bepalen waar het allemaal op staat: Nederlands cabaret (I995) vullen Ibo aan voor de periode I970-1995. Deze goede en nuttige overzichtswerken kunnen uiteraard geen diepgaande analyses en interpretatie bieden van afzonderlijke teksten en oeuvres.

Er wordt het laatste decennium wel onderzoek gedaan naar de Engelstalige popmuziekgolf: zie bijvoorbeeld Tillekens, Het geluid van de Beatles 1998, Mutsaers, Beat Crazy I998 en Righart, De eindeloze jaren zestig 1995 . Het zijn de andere, autochtone, vormen van populaire cultuur die veelal buiten beeld vallen.

:2 Ten overvloede: ook de veranderlijke constructies van mannelijkheid vormen het object van genderstudies. 'Vrouwelijkheid' en het 
gendersysteem hebben in het verleden meer aandacht gekregen, maar het laatste decennium wordt terecht veel feministisch onderzoek gedaan naar mannelijkheid. Zie bijvoorbeeld de twee themanummers van het Tijdschrift voor Vrouwenstudies, no. 49 (De man onder het mes, 1992 en no. 62 (Mannelijkheid? Mannelijkheid!) I995. Het Tijdschrift voor Vrouwenstudies is inmiddels herdoopt tot Tijdschrift voor Genderstudies.

13 Zie voor inleidingen tot de leestheorie of het reader-response-criticism Meijer, De lust tot lezen (1988), Van Alphen, Bij wijze van lezen I988, Culler On Deconstruction 1983 en Flynn and Schweickart (eds) Gender and Reading 1986.

14 Met dank aan C. Meijerink-Brokken. Een korte schets van Brokkens carrière biedt Bart Peeters 'Corry Brokken, de veelzijdige doorzetster' in Frits Gerritsen en Bart Peeters, Roem van toen. Vedetten van de jaren zestig. Apeldoorn: De Ramshorst, I994: 8-13

15 Oorspr. titel Tu te laisses aller, Charles Aznavour. Ned. tekst J. Feldman (Jacques van Tol) _ I960 Internationale Muziek Co. Tekst geciteerd uit Vic van de Reijt (red) Toen wij van Rotterdam vertrokken 1992: 167-169

16 Ik interpreteer deze tekst op twee niveaus: ten eerste op het niveau van de tekst zelf. Ten tweede op het niveau van de positie die deze tekst inneemt in een conglomeraat van verwante populaire liedteksten met hetzelfde thema.

17 Zie over de lyrische taalsituatie Ernst van Alphen e.a. Op poëtische wijze. Handleiding voor het lezen van poëzie. Bussum: Coutinho/ Heerlen: Open Universiteit, $1996:$ 8-38

18 Zie H.J.M.F. Lodewick, Literaire kunst 1965: 101

19 Geciteerd uit Schmidt Tot hier toe 1987: 484-486. Het lied is deel van de musical Heerlijk duurt het langst, die Schmidt in het begin van de jaren zestig schreef. Door veel vertraging vond de première pas plaats in oktober 1965 .

20 Schmidt Tot hier toe 1987: 48r

21 De term pretekst ontleen ik aan Ernst van Alphen, Bij wijze van lezen I988: 229 e.v., 242. Van Alphen spelt 'pretext' en gebruikt de term als vervanger van het gangbare 'context': de historische, biografische en 
ideologische situatie waarin een tekst ontstaat. Het voorvoegsel 'pre' drukt beter uit dat het gaat om de situatie die aan de nieuwe tekst voorafgaat. Naast 'pretext' in bovenstaande betekenis stel ik voor 'pretekst' te reserveren voor de concrete tekst die aangewezen kan worden als concrete voorloper, als machtig model voor de nieuwe tekst. 'Praatgroepen' of 'bewustwordingsgroepen' ontstonden binnen MVM en Dolle Mina in I970 en verbreidden zich vervolgens als een olievlek door de vrouwenbeweging. Het principe was dat door het openhartig praten over het eigen leven en de eigen onvrede de onderdrukkende structuren gezamenlijk zouden kunnen worden ontdekt. Ook zouden vrouwen zich met elkaars hulp kunnen ontdoen van verinnerlijkte patriarchale visies. Op die manier konden vriendschap en solidariteit tussen vrouwen ontstaan. Zie voor een geschiedenis van de feministische bewustwording in Nederland I965-1980 Irene Costera Meijer, Het persoonlijke wordt politiek Amsterdam: Het Spinhuis 1996

${ }_{23}$ 'Ik moet weg' is een bewerking van 'Gotta move' en dateert uit ${ }^{9} 6_{7}$. Tekst door mij getransscribeerd van CD Corry Brokken. Net als toen. Een hommage aan een onvergetelijke zangeres. PG 899 LC 0268, 522 864-2 Phonogram 1994

${ }_{24}$ Tekst door mij getransscribeerd van CD Corr $\gamma$ Brokken. Net als toen. PG 899 LC 0268, 522 864-2 Phonogram I994

25 Zie Gayle Rubin, 'The Traffic in Women: Notes on the Political Economy of Sex' in: Rayna R. Reiter (ed) Toward an Anthropology of Women New York: Monthly Review Press, 1975: 157-210; Eve Kosofsky Sedgwick, Between Men: Homosocial Desire and the English Novel. New York: Columbia University Press, 1985

26 Maaike Meijer, In tekst gevat Amsterdam: Amsterdam University Press 1996

27 In deze categorie valt bijvoorbeeld ook Annie Schmidts 'Wij en zij' uit de eerste helft van de jaren '50 (Schmidt Tot hier toe 1987: 314)

${ }_{28}$ Er zijn ook vrouwelijke schrijvers voor mannelijke zangers: Belinda Meuldijk schrijft de teksten voor Rob de Nijs, zie De Nijs en Meuldijk, Over leven I997 
De kwestie van het auteurschap is in het lied complex. Het is minimaal drievoudig: de componist en de tekstschrijver/schrijfster zijn beiden auteur, maar ook de zanger/zangeres die het lied belichaamt en interpreteert kan als mede-auteur worden opgevat. Verschillende uitvoeringen kunnen dramatisch van elkaar verschillen. Wanneer het gaat om vertaalde of bewerkte liederen drukken ook de eerdere zanger/zangeres en de vertaler hun stempel. 'Ali Cyaankali' is een liedje uit het radiofeuilleton 'De familie Doorsnee'. Schmidt Tot hier toe $1987: 248$

${ }_{31}$ Schmidt, Tot hier toe $1987: 48 \mathrm{I}$

32 Schmidt, Tot hier toe 1987: $484-485$

33 meer voorbeelden: 'Als er geen mannen waren' uit Schmidts 'De familie Doorsnee' (I952-I958); 'Neem alles maar terug', een cabaretliedjes van Schmidt uit de periode I95I-I955 - waar de vrouw overigens uit wraak op haar naar ene Lena lonkende echtgenoot zelf ostentatief een heer op visite laat komen.

34 Met dank aan renee hoogland

35 Kea Tijdens (1995) maakt melding van een telling uit 1947, waaruit bleek dat $98 \%$ van de gehuwde vrouwen uitsluitend in haar eigen huishouding werkte. Dit percentage steeg in de jaren vijftig slechts zeer langzaam.

${ }_{36}$ Overtuigend gedemonstreerd door Tillekens, Het geluid van de Beatles 1998

37 The Beatles, Lyrics I975: 42 
Machtige melodieën 


\section{Gebruikte literatuur:}

Alphen, Ernst van, Bij wijze van lezen. Verleiding en verzet van Willem Brakmans lezer. Muiderberh: Coutinho, 1988

Alphen, Ernst van, Lizet Duyvendak, Maaike Meijer en Ben Peperkamp, Op poëtische wijze. Handleiding voor het lezen van poëzie. Bussum: Coutinho/ Heerlen: Open Universiteit, 1996

Beatles, the, Lyrics. With an introd. by J. Savile. repr. London: Futura 1975

Becker, H.A. 'Generaties. Vergrijzing en maatschappelijke ongelijkheid' in: Munnichs (red) Psycho-gerontologie Deventer: Van Loghum Slaterus, I983

Costera Meijer, Irene, Het persoonlijke wordt politiek. Feministische bewustwording in Nederland 1965-1980. Amsterdam: Het Spinhuis, I996

Culler, Jonathan, On Deconstruction. London: Routledge \& Kegan Paul, 1983

Duyvendak, J.W. e.a. (red) Tussen verbeelding en macht. 25 jaar nieuwe sociale bewegingen in Nederland. Amsterdam: Sua, 1992

Flynn, Elizabeth and Patrocinio Schweickart (eds) Gender and Reading: Essays on Readers, Texts and Contexts. Baltimore/London: Johns Hopkins University Press, 1986

Gerritsen, Frits, Roem van toen. Vedetten van de jaren zestig. Fotografische herinneringen van Frits Gerritsen met teksten van Bart Peeters en een voorwoord van Anneke Grönloh. Apeldoorn: De Ramshorst, I994

Hanenberg, Patrick van den en Frank Verhallen, Het is weer tijd om te bepalen waar het allemaal op staat. Nederlands cabaret 1970-1995. Amsterdam: Nijgh \& Van Ditmar, 1996 
Ibo, Wim, En nu de moraal...: geschiedenis van het Nederlands cabaret. Alphen aan den Rijn: Sijthoff, I98I-I982

J.E. Kool-Smit, 'Het onbehagen bij de vrouw' in: De Gids 130 (1967): 267-28r

Kriesi, H. en P. Castenmiller 1987, 'De ontwikkeling van politiek protest in Nederland sinds de jaren zeventig' in: Acta Politica, I

Lauretis, Teresa de, Technologies of Gender. Essays on Theor, Film and Fiction. Bloomington and Indianapolis: Indiana University Press, 1987

Lodewick, H.J.M.F. Literaire kunst. 23e herz. druk, 's Hertogenbosch: Malmberg, 1965

Meijer, Maaike, De lust tot lezen. Nederlandse dichteressen en het literaire systeem. Proefschrift. Amsterdam: Van Gennep/Sara 1988

Meijer, Maaike, 'Paarse September. Een documentaire' in: Gert Hekma e.a. (red) Goed verkeerd Amsterdam: Meulenhoff i989: 183-197

Meijer, Maaike, 'Inleiding' in: Ankie Peijpers, Gedichten 1951-1975 Amsterdam: An Dekker I99I: i-xiii.

Meijer, Maaike, In tekst gevat. Inleiding tot een kritiek van representatie. Amsterdam: Amsterdam University Press 1996

Mutsaers, Lutgard, Beat Crazy. Een pophistorisch onderzoek naar de impact van de transnationale dansrages twist, disco en house in Nederland. Proefschrift. Utrecht: eigen beheer 1998

Nijs, Rob de en Belinda Meuldijk, Over leven. Liedteksten 1981-1997 Baarn: De Prom 1997 
Oldenziel, Ruth en Carolien Bouw (red) Schoon genoeg. Huisvrouwen en huishoudtechnologie in Nederland 1898-1998 Nijmegen: Sun, 1998

Reijt, Vic van de (red) Toen wij van Rotterdam vertrokken. Nederlandse liederen uit de 2oe eeuw. 8e druk. Amsterdam: Bert Bakker, 1992

Righart, Hans, De eindeloze jaren zestig. Geschiedenis van een generatieconflict. Amsterdam: Arbeiderspers 1995

Rubin, Gayle, 'The Traffic in Women: Notes on the Political Economy of Sex' in: Rayna R. Reiter (ed) Toward an Anthropology of Women New York: Monthly Review Press, I975: 157-210

Sedgwick, Eve Kosofsky, Between Men: Homosocial Desire and the English Novel. New York: Columbia University Press, 1985

Schmidt, Annie, Ziezo. De 347 kinderversjes. Amsterdam: Querido, I987

Tijdens, Kea, 'Verdwijnt de huisvrouw?' in Sociaal Maandblad Arbeid 50 (I995): IGI-I70

Tijdschrift voor Vrouwenstudies, 13 (1992) no. 49, themanummer De man onder het mes. Nijmegen: SUN

Tijdschrift voor Vrouwenstudies, 16 (1995) no. 62, themanummer Mannelijkheid? Mannelijkheid! Over bankovervallers, eenzame helden, zorgverlof en het duel. Nijmegen: SUN

Tillekens, Ger, Het geluid van de Beatles. Een muzieksociologische studie. Proefschrift. Amsterdam: Het spinhuis, $199^{8}$

Veeger, Petra, Manoeuvres. Proza uit de jaren vijftig en zestig, Delft: Eburon 1996. 
Machtige melodieën

Voogd, Stephanie de, 'Feminisme en homoseksualiteit' in: Paarse September no. 3, maart 1973

Wijfes, Huub (red) met Eric Smulders, Omroep in Nederland. Vijfenzeventig jaar medium en maatschappij, 1919-1994. Zwolle: Waanders I994 
